This Section of Epidemiology and Psychiatric Sciences appears in each issue of the Journal and is dedicated to all forms of creative production born of an intimate and individual urge, often secretive, unbound from the conventional art system rules. Through short descriptions of the Outsider art work of prominent artists and new protagonists often hosted in community mental health services, this section intends to investigate the latest developments of the contemporary art scene, where the distances between the edge and the center are becoming more and more vague.

Carole Tansella, Section Editor

\title{
Auguste Forestier's unbroken wanderlust
}

\author{
Savine Faupin \\ LaM Lille Métropole Musée d'art moderne, d'art contemporain et d'art brut, Villeneuve-d' Ascq
}

Received 27 October 2016; Accepted 28 October 2016; First Published online 28 November 2016

Key words: History of psychiatry, mental health, outsider art, psychiatric hospital.

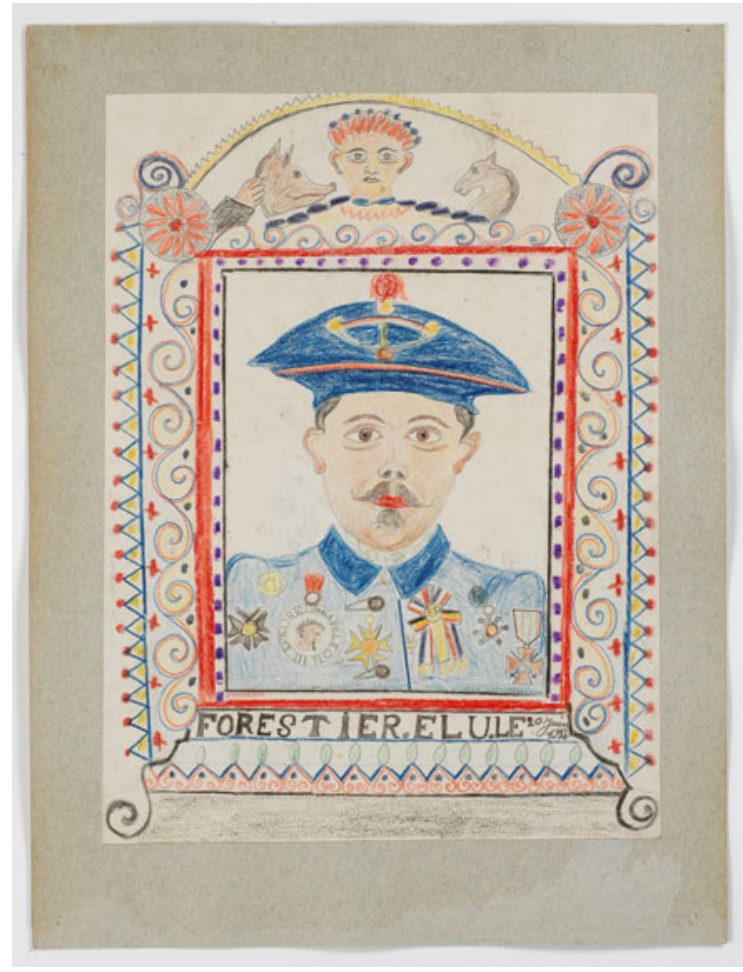

Auguste Forestier, Forestier élu le 20 juin 1914, c. 1914, colour pencil on paper, $31.7 \times 23.7 \mathrm{~cm}$, inv. 2007.5.1, LaM, photo: Cecile Dubart.

Address for correspondence: LaM, 1 allée du Musée, 59650 Villeneuve-d'Ascq, France.

(Email: sfaupin@musee-lam.fr)

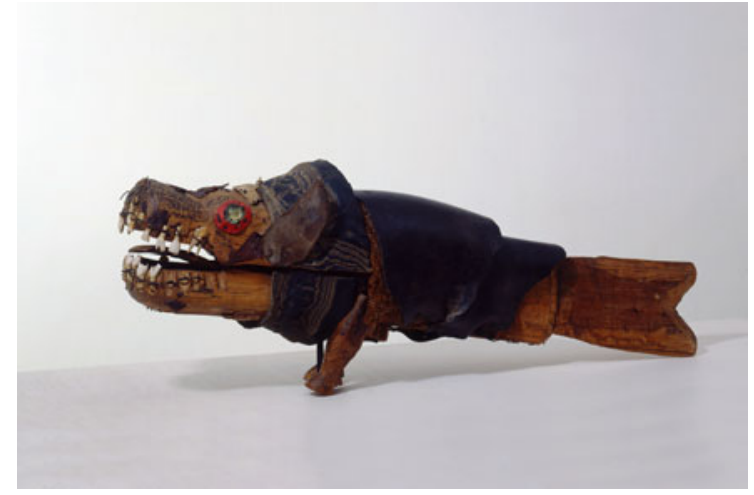

Auguste Forestier, La bête du Gévaudan, c. 1940, wood, leather, metal, rubber, tooth, glass, 31, $5 \times 89 \times 26 \mathrm{~cm}$, inv. 999.43.15, Donation L'Aracine, LaM, photo: Philip Bernard.

Auguste Forestier (Naussac, 1887-Saint-Alban-surLimagnole, 1958) began running away as an adolescent taking the train without a ticket for long journeys. His longing for the faraway may explain these repeated escapades. He was brought back to his village each time by the police. Fascinated by trains, he caused a derailment in a tunnel in May 1914 by placing stones on the tracks. Upon his arrest he explained: 'I wanted to see how the stones got crushed, and it didn't occur to me that I could derail the train'. In prison he carved wooden medals, saying they had been given to him by the railway company as a sign of their appreciation.

Forestier was not convicted of damaging public property, but deemed unaccountable for his actions 
and committed to the asylum at Saint-Alban in Lozère. In 1915, a year after his committal, it is reported that he 'is often occupied with drawing and carving bones from the butcher shop. He works very hard, achieving a kind of primitive artistry'. The hospital was at the time being run by Maxime Dubuisson (1851-1928), a physician who was interested in the work produced by the patients and assembled two volumes of drawings, many of which had been done by Forestier. But Forestier's wanderlust was unbroken: he ran away a total of five times between 1914 and 1923, yet he gradually began substituting his real travels with other forms of departure. His drawings and sculptures took him on fictitious journeys through history. The psychiatrist Jean Oury (1924-2014), who worked at Saint-Alban from 1947 to 1949 and treated Forestier, made the following comment: 'This transformation from a nomad into a sedentary man can only be the logical result of the transformation of a traveler into a producer. But Forestier's work will always bear traces of the ideal of the traveler' (Oury, 1956).

Forestier's imaginary world was enriched by the place where he lived. The hospital was housed in an old 13th-century castle extended in the 16th century by four towers. The exterior walls are massive; only the main door and the window above it were decorated with pilasters and gables in pink sandstone. Forestier was not indifferent to this door either; it symbolised both his incarceration and an opening out into the world. He placed his sculptures near this portal in order to trade them with hospital staff or sell them to farmers passing through, who would buy them as toys for their children (Oury, 2005).

Forestier had created a kind of workshop in a corridor that leads from the scullery to an inner courtyard: a workbench, some rudimentary tools, a small chisel, a knife and nails. He wandered about the hospital to glean broken objects and discarded remnants of fabric. He carved arms, legs, heads, wings, decorative mouldings and more out of the pieces of wood he had collected (Dubuffet, 1966). Forestier achieved a high degree of technical skill and speed that enabled him to manufacture a variety of objects. He constructed his figures, soldiers, boats, horsemen, animals, houses, furniture for children and carts according to a combinatory principle that became his unmistakable trademark.

The man-animal metamorphosis is very important for Forestier. We must not forget that the story of the terrible beast of Gévaudan terrorised the people of Lozère from 1764 to 1767 and the villages of the Margeride told tales of numerous victims of the legendary 'werewolf.' The monsters sculpted by Forestier undoubtedly evoke the famous beast: they have the muzzles of wolves, the tails of fish, but also feature parts of birds - several of them have wings growing out of their back - and naturally, human beings, because they stand on two feet. They can fly, swim and walk. Wrapped in clothes made from remnants of fabric and decorated with medals, strange fellows have a human head and body but a bird's beak. Others, sometimes referred to as 'roosters', have both wings and feet (Faupin, 2007).

Because he no longer ventured outside the hospital walls, Forestier, the stationary traveller, invented imaginary means of travel. Although he never saw the sea, he devised ships and set them to sail on the roads of Lozère by selling and trading them. This is symbolically illustrated in the photograph featuring the psychiatrist François Tosquelles holding a ship made by Forestier over the roofs of Saint-Alban as if it were a ship of fools. Paul Éluard, a clandestine refugee at Saint-Alban in 1943 thanks to the psychiatrist Lucien Bonnafé, wrote his volume of poetry Souvenirs de la maison des fous (Memories of the Madhouse) there, and came into contact with Forestier. He would take back to Paris several sculptures to show them to Pablo Picasso and Raymond Queneau - yet another journey, which, however, this time transported him into an artistic environment.

\section{Acknowledgements}

The author thanks Carole Tansella.

\section{Financial support}

This research received no specific grant from any funding agency, commercial or not-for-profit sectors.

\section{Conflict of Interest}

None.

\section{References}

Dubuffet J (1966). La fabrique d'Auguste, L'Art Brut 8. Publications de la Compagnie de l'Art Brut dirigée par Jean Dubuffet: Paris.

Faupin S (2007). Le voyageur Immobile. Musée d'art moderne Lille Métropole: Villeneuve d'Ascq.

Oury J (1956). Auguste For. Bizarre VI.

Oury J (2005). Essai sur la conation esthétique. Le Pli: Orléans.

\section{About the Author}

Savine Faupin is Chief Curator in charge of Outsider Art at LaM, Musée d'art Moderne, d'Art 
Contemporain et d'Art Brut, Villeneuve d'Ascq, France, an unique example of Museum where Art Brut is exhibited alongside modern and contemporary art. Among the exhibitions she has curated, Aloïse Corbaz en constellation (2015); L'Autre de l'art (2015); $L^{\prime}$ 'Aracine et l'art brut (2009). She is author of numerous publications, including Art brut: une avant-garde en moins? (2009); Des fantômes $\mathcal{E}$ des anges (2007); Les chemins de l'art brut à Saint-Alban-sur-Limagnole (2007); Dubuffet et l'Art Brut (2005).

Carole Tansella, Section Editor 